\title{
Studies on Cholera Toxin and Antitoxin
}

\author{
By J. UNGAR, M. STANIĆ, N. CHARIATTE AND \\ S. J. VARALLYAY \\ Swiss Serum and Vaccine Institute, Berne, Switzerland
}

(Accepted for publication 2 September 1970)

\begin{abstract}
SUMMARY
The preparation, purification and properties of cholera toxin type 2 are described. When the toxin was given to experimental animals it induced a high level of toxin-neutralizing antibodies. Cholera toxoid given to human volunteers induced antibodies consisting of agglutinins, vibriocidal and toxin-neutralizing antibodies. The relevant titres depended on the purity of the antigen administered.
\end{abstract}

\section{INTRODUCTION}

The protective value of whole-cell cholera vaccines has been demonstrated in the last six years in field trials conducted in the Philippines (Azurin et al. 1967) and in East Pakistan (Oseasohn, Benenson \& Fahimuddin, 1965; Benenson, Mosley, Fahimuddin \& Oseasohn, I $968 \mathrm{~b}$; Mosley et al. I969) when $50 \%$ of the people inoculated were shown to be protected but only for a short time. The duration of the protection can be prolonged up to I 8 months either by using vaccines of extremely high mouse potency or by repeated inoculations (Oseasohn et al. 1965; Benenson et al. 1968b). As the protection produced by whole-cell cholera vaccines and endotoxin preparations seems to be only partially effective (Watanabe \& Verwey, I965), it is of particular importance to determine the protective effect of the cholera toxin preparation in man. In a recent review Burrows (I968) summarized the characteristics of three toxins of Vibrio cholerae. Dutta \& Habbu (1955) introduced the suckling rabbit test which later was developed by Finkelstein, Norris \& Dutta (1964) for the studies of the thermolabile, nondialysable type 2 'choleragenic' toxin which plays an important role in the pathogenesis of cholera. Craig (I965, I966) found a factor in the filtrate of vibrios, thermolabile and non-dialysable. He later described a method for the titration of this factor, which he referred to as the 'permeability factor' (1966).

We decided to investigate the protective value of antigens prepared from the type 2 toxin. For this purpose we prepared the toxin according to the method described briefly in a previous communication (Ungar, Chariatte, Stanić \& Varallyay, 1969) and given below in detail.

\section{METHODS}

Strains. All the strains used in our investigation were freeze-dried after isolation and stored at $4^{\circ}$. The toxigenic strain Vibrio cholerae 569 B serotype INABA came from Dr R. A. Finkelstein. To determine the prevalence of toxin production among classical and EL TOR vibrios isolated from cholera patients, various vibrios (D34580 and D 34580GP from East Pakistan) and EL TOR biotypes (no. I33, 282 and 929 from the Middle East) were cultivated and their culture filtrates tested for toxicity. 
Media. In the early experiments syncase medium (Finkelstein, Atthasampunna, Chulasamaya \& Charunmethee, I966) was used. The peptone water medium contained $30 \mathrm{~g}$. Bacto-peptone (Difco)/l. and $5 \mathrm{~g}$. NaCl/1. at $\mathrm{pH} 8 \cdot 0$. The dialysed peptone water used in later experiments contained the same amount of Bacto-peptone and $\mathrm{NaCl}$ but the peptone had been previously dialysed against deionized water. A $30 \%$ (w/v) solution in deionized water was dialysed against 20 vol. of deionized water, with vigorous magnetic stirring for $24 \mathrm{~h}$. at $4^{\circ}$. The dialysate was concentrated and freezedried. These small dialysable molecules of peptone were used instead of the untreated product in order to facilitate the separation by dialysis of unaltered medium from the bacterial products in the crude supernatant of the cholera cultures. The dialysis tubing (Kalle AG, 6206 Wiesbaden-Biebrach, West Germany) was sterilized by boiling in distilled water. The stock cultures were rehydrated from the freeze-dried state by the addition of nutrient broth and inoculated on Bacto-peptone agar containing peptone water plus $2 \%$ Bacto agar (Difco).

Cultures. The vibrios were cultivated in I 1 . Erlenmeyer flasks containing $200 \mathrm{ml}$. medium on a rotating shaker (I30 rotations/min. (rev./min.)) at $37^{\circ}$ for $7 \mathrm{~h}$. Alternatively, a stainless steel 51 . laboratory fermenter was used in which the medium was stirred at $1400 \mathrm{rev} . / \mathrm{min}$ and aerated with air $(500 \mathrm{ml} . / \mathrm{min}$.). The air was sterilized by a closed system of 2 Berkefeld N-I 5 filters. To prevent the formation of foam, I ml. of a $25 \%$ (w/v) silicone-paraffin oil emulsion (Dow Corning Antifoam A) was added.

\section{Toxin production}

Inoculation of flasks and fermenters. The freeze-dried Vibrio cholerae strain $569 \mathrm{~B}$ was recovered, streaked on to $3 \%(\mathrm{w} / \mathrm{v})$ peptone agar and cultivated at $37^{\circ}$ for $18 \mathrm{~h}$. The surface growth was washed off with physiological saline, and the suspension adjusted to $\mathrm{I} \cdot 4 \times \mathrm{IO}^{9}$ vibrios $/ \mathrm{ml}$. using Brown's opacity tubes (Wellcome). Two $\mathrm{ml}$. of the suspension were used as inoculum for the $200 \mathrm{ml}$. shaken culture, grown at $37^{\circ}$ for $7 \mathrm{~h}$. and then used as inoculum for the 51 . fermenter. The fermenter was incubated at $36^{\circ}$ for $6.5 \mathrm{~h}$. When the culture reached the end of the logarithmic phase it was harvested by centrifugation at $6100 \mathrm{~g}$ using a Sorvall $\mathrm{RC}-2 \mathrm{~B}$ superspeed refrigerated centrifuge at $4^{\circ}$.

To achieve rapid filtration through the final GS $(0.22 \mu \mathrm{m}$.) membranes, prefiltration of the supernatant was necessary through RA (I.2 $\mu \mathrm{m}$.), DA $(0.65 \mu \mathrm{m}$.) and HA $(0.45 \mu \mathrm{m}$.) membranes, with AP 32 Dacron mesh between each pair of membranes. All the membranes were put in a single, $142 \mathrm{~cm}$. filter holder with an AP 25 glass fibre prefilter. The product was our crude syncase choleragen or, in the case of the peptone media, the crude peptone water supernatant (PSUP) toxin. The products were stored at $4^{\circ}$ until purification. Table I summarizes the yields of the toxin obtained under various growth conditions.

Purification of the toxin. The crude cholera toxin was precipitated by $90 \%$ saturation with ammonium sulphate or concentrated by flash evaporation (Rotavapor $R$, Büchi AG, Flawil/SG, Switzerland).

Purification was first tried on Sephadex G-200 by eluting with 0.I M-tris buffer, $\mathrm{pH} 7 \cdot 5$. But as the flow rate was slow, the gel was replaced by Sepharose $4 \mathrm{~B}$ and the elutions were performed with $0.1 \mathrm{M}$-tris buffer $\mathrm{pH} \mathrm{8.6.} \mathrm{The} \mathrm{extinction} \mathrm{of} \mathrm{the} \mathrm{eluates}$ was monitored at $253.7 \mathrm{~nm}$. with an LKB 8300 A Uvicord II (LKB Produkter AB, Stockholm, Sweden). At a later stage, the cholera toxin was purified on DEAE 
cellulose by stepwise elution with distilled water, 0.05 and $0.5 \mathrm{M}-\mathrm{NaCl}$. The properties of the purified material were assessed by immunoelectrophoresis and gel diffusions and measurements of loop toxicity. For the characterization of the purified toxin, total nitrogen and protein determinations were of little value.

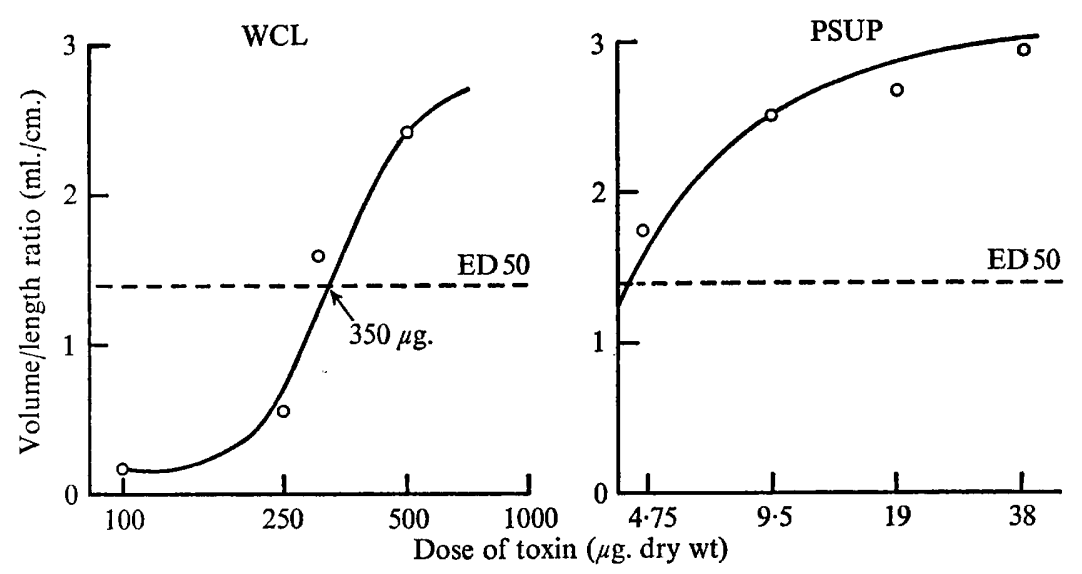

Fig. I. Typical toxin titration curves of a whole cell lysate (WCL) and a crude peptone water supernatant (PSUP) toxin in the adult rabbit ileal loop. I unit of WCL toxin = approximately $350 \mu \mathrm{g}$. dry wt of toxin and I unit of PSUP toxin $=2 \mu \mathrm{g}$. dry wt of toxin.

\section{Table I. Yield of the toxin from Vibrio cholerae under different growth conditions}

Cultures were grown as described in Methods (p. 2) for $7 \mathrm{~h}$. (shaken cultures) or $6.5 \mathrm{~h}$. (fermenter cultures). The bacteria were removed by centrifugation and the supernatant passed through membrane filters. The toxin content of the filtrate was assayed using the ileal loop technique.

$\begin{array}{lcc}\text { Medium } & \text { Shaken flasks } & \begin{array}{c}\text { Five-litre } \\ \text { fermenter }\end{array} \\ \text { Syncase } & 50 \text { to } 400 & 50 \text { to } 600 \\ \text { Peptone } & 400 \text { to } 1000 & 200 \text { to } 1000 \\ \text { Dialysed peptone } & 400 \text { to } 1200 & 200 \text { to } 1200\end{array}$

Titration of the toxin and antitoxin. All toxin and antitoxin titrations were performed according to the method of Kasai \& Burrows (1966) and are designated in the text as toxin loop units and AT (antitoxic) units respectively. We used non-inbred albino rabbits of both sexes, aged 8 to I 2 weeks, from the Tierzuchtinstitut,Zürich, Switzerland. Other strains of rabbits of the same age were also tried but their resistance to the toxin was irregular. The animals were starved for $48 \mathrm{~h}$. before the operation but were always allowed free access to water. The animals were killed by intravenous injection of sodium pentothal, and autopsy was performed between $\mathrm{I} 8$ and $20 \mathrm{~h}$. after injection of the toxin. The volume of fluid $(V)$ in each loop (expressed in $\mathrm{ml}$.) and the length $(L)$ of the loops (expressed in $\mathrm{cm}$.) was measured and the ratio $(V / L)$ calculated. Values higher than 2.75 were not considered in the calculation of the averages. The ED 50 reaction was therefore a $V / L$ value of $I \cdot 375$, and this was taken as one unit of type 2 cholera toxin, as described by Kasai \& Burrows (1966).

Fig. I illustrates two typical toxin titrations. The titration of toxin-neutralizing 
antibodies was also performed in the ligatured ileal loop of adult rabbits, but in this case a neutralization coefficient $(N C)$ was calculated from the $V / L$ ratios $(N C=\mathrm{I}-[2 \cdot 75 / V / L])$. The $N C$ was plotted on a log scale against the dilutions of the antiserum. In these neutralization tests a sonic lysate of cholera toxin, kindly supplied by Dr W. Burrows, was used as a standard.

Preparation of the toxoid. The crude and purified cholera toxins from syncase, peptone water and dialysed peptone water medium were treated with $0.25 \%$ formaldehyde (E. Merck, 35\% (w/v) analytical grade) at room temperature for I week. After detoxification, the residual formaldehyde was removed by dialysis at $4^{\circ}$ against distilled water for 3 days; the toxoid was tested in the ileal loop for its innocuity.

Preparation of antisera. Antisera were prepared by immunizing rabbits. A single injection of I or $2 \mathrm{ml}$. toxin ( 0.5 , or $2 \mathrm{mg}$.) without adjuvant was given to each rabbit intramuscularly or intraperitoneally and blood specimens taken 2 or 3 weeks later. The presence of specific antibodies against the crude PSUP toxin could be shown using the agar immunodiffusion technique.

As large amounts of high titre antiserum were needed to study the role of the antibodies in the prevention and treatment of cholera, a horse was hyperimmunized intramuscularly with purified cholera toxin, using aluminium phosphate as an adjuvant. When the titre of the antitoxin in the serum was found to be satisfactory (2000 to 2500 AT units $/ \mathrm{ml}$.) the horse was bled and the plasma purified.

Precipitation of the low molecular weight proteins from the horse plasma was performed by adding $0.5 \%$ rivanol at $\mathrm{pH} 8.0$, followed by fractionation of the nonprecipitated immunoglobulins with either $(a) 2$ moles sulphate/l. at neutral $\mathrm{pH}$, or $(b)$ ethanol at $-7^{\circ}$ and neutral $\mathrm{pH}$. In both cases filtration and lyophilization of the precipitate was performed and the protein content adjusted to $10 \%$; the yield of gammaglobulin was 65 to $70 \%$ by method $(a)$ and 83 to $85 \%$ by method $(b)$. The solution was made isotonic by the addition of sodium chloride and then sterilized by filtration through Millipore GS membrane filters. Thiomersal (0.01 \%) was added as a preservative.

\section{Serological methods}

Agglutinins were determined using a suspension of live vibrios according to the method of Goodner, Smith \& Stempen (I960).

Vibriocidal antibodies were determined either by the method of Finkelstein (1962) or by the microtechnique of Benenson, Anisa Saad \& Mosley (I968a) using the Microtiter System (Cooke Engineering Co., Alexandria, Va, U.S.A.) as recommended by Sever (1962).

Antitoxins were titrated by the ileal loop technique described by Kasai \& Burrows (I966).

\section{RESULTS}

Strains. Fig. 2 shows the results of comparative titrations carried out in duplicate. The abscissa give the dilution of the PSUP toxin from cultures of different 'classical' (D34580 and D34580 GP) and EL TOR (I33, 282, 929) vibrios. The variations in the quantities of toxin produced by the strains agreed with the findings of other workers (De, Ghose \& Sen, I960; Finkelstein et al. 1964; Burrows, 1968).

Media. A culture supernatant containing crude toxin could be obtained with the strain 569 в by incubating in syncase medium for 18 to $20 \mathrm{~h}$. at $37^{\circ}$ on a rotating shaker. 
The amount of the toxin varied between 100 to 400 loop units $/ \mathrm{ml}$. We noted that for toxin production the ratio of the surface of the medium to the volume in the Erlenmeyer flask was of considerable importance ( $200 \mathrm{ml}$. medium in I 1. Erlenmeyer flask). Static cultures did not yield supernatants with measurable loop toxicity. Cultures (either shaken or fermenter) grown on Bacto-peptone and the dialysed Bacto-peptone media always produced toxin in the logarithmic phase of the growth and the culture filtrates contained Ioo to I000 loop units $/ \mathrm{ml}$. On the other hand, in the syncase medium toxin was only occasionally produced in the logarithmic phase, but atoxicity comparable to the peptone media was reached after 18 to $20 \mathrm{~h}$. incubation when the culture was entering the stationary phase.

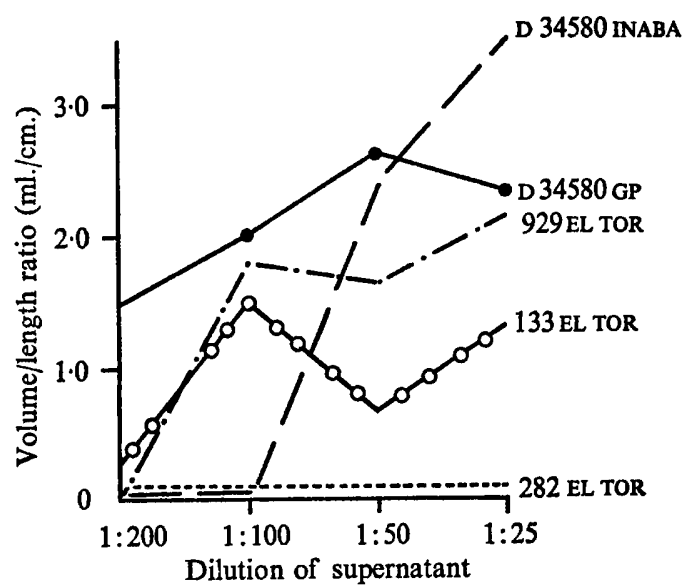

Fig. 2. Comparison of the toxigenicity of various classic and EL TOR biotypes of Vibrio cholerae. Crude peptone water supernatant toxin was isolated from shaken cultures and assayed in the ileal loop of adult rabbits.

Purification of the crude toxin. When the crude syncase or PSUP toxin preparation was chromatographed on Sephadex G-20o two peaks of material were eluted. The first contained the toxin and the second was unchanged ingredients of the culture medium and contained no toxin. The material in the first peak gave two precipitin lines on gel diffusion. When the antigenic properties of these peak materials were determined it was found that the material in the first peak stimulated the formation of toxinneutralizing antibodies and the material in the second peak gave rise to vibriocidal antibodies. Fractionations on Sepharose $4 \mathrm{~B}$ with $0 \cdot 1 \mathrm{M}$-tris buffer, $\mathrm{pH} 8 \cdot 6$, gave similar results. On gel diffusions no interference reaction (Ouchterlony) was found with the two precipitin lines produced by material derived from the Sephadex G-200 fractionation.

Considerably better resolution was obtained when DEAE cellulose was used. The material eluted in deionized water contained the major portion of toxicity and gave a single precipitin line on gel diffusion. Further elution with 0.05 and $0.5 \mathrm{M}-\mathrm{NaCl}$ gave two more fractions. The latter gave a broad band of precipitin and two distinct precipitin lines on gel diffusion but no biological (loop) activity was detected. The precipitin line of the water subfraction gave an interference reaction (Ouchterlony) with the precipitin lines of the $\mathrm{NaCl}$ fractions. Immunogenic studies in rabbits showed that the water fraction produced antitoxin, whereas the $0.5 \mathrm{M}-\mathrm{NaCl}$ fraction produced vibriocidal antibodies. 


\title{
Characteristics of the toxin
}

Stability. The crude PSUP toxin or syncase choleragen was stored at $+4^{\circ}$ and its loop toxicity tested at intervals of 4,8 and 12 weeks. This activity diminished by between 80 and $90 \%$ after 8 to 12 weeks. After freezing the toxin at $-70^{\circ}$ for 4 weeks, the toxin showed a similar loss of activity. Lyophilization studies showed that when the final drying was carried out at $23^{\circ}$ up to $60 \%$ of the activity was lost, and if done at $30^{\circ}$ as much as $70 \%$ was lost.

Toxicity. When $0.1 \mathrm{ml}$. (5 units) of the toxin was injected intradermally into a guinea pig, a reddening and induration was produced after $12 \mathrm{~h}$. which reached a diameter of $25 \mathrm{~mm}$. after $48 \mathrm{~h}$. No necrosis was noted.

\section{Table 2. Types and titres of antibodies present in purified globulins prepared from horse antiserum}

\begin{abstract}
Antiserum was prepared by hyperimmunization of a horse, using purified cholera toxin (from Vibrio cholerae 569 B). The immunoglobulins were precipitated (Methods, p. 2) and lyophilized. A solution containing $10 \%$ protein was prepared, made isotonic with $\mathrm{NaCl}$ and sterilized. The titre of agglutinating antibodies was determined using suspensions of $V$. cholerae INABA strain 569 B and OGAWA strain C 38383 .
\end{abstract}

\begin{tabular}{|c|c|c|c|c|}
\hline \multirow{3}{*}{$\begin{array}{l}\text { Batch no. and } \\
\text { method of preparation }\end{array}$} & \multicolumn{4}{|c|}{ Reciprocal titres } \\
\hline & \multirow{2}{*}{$\begin{array}{l}\text { Antitoxic } \\
\text { antibodies }\end{array}$} & \multirow{2}{*}{$\begin{array}{l}\text { Vibriocidal } \\
\text { antibodies }\end{array}$} & \multicolumn{2}{|c|}{$\begin{array}{l}\text { Agglutinating } \\
\text { antibodies }\end{array}$} \\
\hline & & & INABA & OGAWA \\
\hline $\begin{array}{l}\text { A-2/67 Rivanol- } \\
\text { ammonium sulphate } \\
\text { fractionation }\end{array}$ & 24,000 & $\begin{array}{c}10^{7 *} \\
5 \times 10^{4} \text { to } 1.5 \times 10^{5} \dagger\end{array}$ & I 280 & 1280 \\
\hline $\begin{array}{l}\text { A-1/68 Rivanol- } \\
\text { ammonium sulphate } \\
\text { fractionation }\end{array}$ & 22,000 & $10^{7}$ & 5120 & 5120 \\
\hline $\begin{array}{l}\text { B-I/68 Rivanol- } \\
\text { ethanol fractionation }\end{array}$ & $\begin{array}{r}30,000 \text { to } 40,000 \\
* \text { By the meth } \\
+ \text { By the meth }\end{array}$ & $\begin{array}{l}10^{5} \\
d \text { of Finkelstein (I } \\
d \text { of Sack et al. (IS }\end{array}$ & 2560 & 2560 \\
\hline
\end{tabular}

Pyrogenicity. When injected intravenously into rabbits, $0 \cdot \mathrm{I} \mathrm{ml}$. ( 5 units) $/ \mathrm{kg}$. body weight produced a rise in temperature of 0.6 to $0.8^{\circ}$, i.e. the toxin was slightly pyrogenic.

Detoxification. Formaldehyde concentrations greater than $0.25 \%$ destroyed the ileal loop activity after $6 \mathrm{~h}$. at temperatures from 4 to $22^{\circ}$.

Tests in animals. The antigenicity of the toxin and of the toxoid was tested in rabbits immunized intramuscularly. The serological response of rabbits to a single dose of 50 loop-units of the toxin was as follows: agglutinin titres varied between I : I280 and $\mathrm{I}: 10,240$, while vibriocidal antibody titres varied between $\mathrm{I}: 10^{4}$ and $\mathrm{I}: 5 \times 10^{6}$. Antitoxin titres 3 weeks after immunization were between 1600 and 2400 antitoxin (AT) units. The agglutinin and vibriocidal antibody titres in rabbits immunized with the same amount of toxin (previously treated with $0.1 \%$ formaldehyde for $24 \mathrm{~h}$.) showed titres of $I: I 280$ to $I: 2560$ and $I: I 0^{4}$ to $I: 10^{5}$ respectively. Immunization with the partially inactivated toxin, which was obtained by treatment with $0.05 \%$ formaldehyde for $\mathrm{I} h$., also produced agglutinins, vibriocidal antibodies and titres of 
antitoxin (200 to 400 units $/ \mathrm{ml}$.) similar to those following injection of toxin treated with $0.1 \%$ formaldehyde.

During the hyperimmunization of the horse, doses of the purified toxin (50 to $100 \mathrm{ml}$. of the eluate derived from Sephadex G-200 and containing 5 to $10 \mathrm{mg}$. protein $/ \mathrm{ml}$.) produced general symptoms, such as rise in temperature and increased perspiration, which disappeared in 4 to $6 \mathrm{~h}$. After six repeated doses of this toxin, the antitoxin level was usually between I 500 and $2500 \mathrm{AT}$ units $/ \mathrm{ml}$. which decreased after 3 to 4 weeks to 500 to 600 units $/ \mathrm{ml}$. Repeated immunization was needed to maintain the high antitoxin titres. As in the rabbit sera, the agglutinin and vibriocidal antibody titres of the horse serum increased to $\mathrm{I}: 10^{4}$ and $\mathrm{I}: 10^{5}$ respectively.

Biological control tests of the horse antitoxin conformed to the requirements laid down by the U.S. PHS Regulations Title 42 regarding the General Safety Test (part 73.72) in mice and stability conformed to the N.I.H. Minimum Requirements for Gammaglobulins.

Pyrogen tests (according to part 73.74, 'purity' of the above U.S. PHS Regulations) with the rivanol-ammonium sulphate purified serum showed a slight pyrogenicity ( $\mathrm{I} \cdot \mathrm{O}$ to $\mathrm{I} \cdot 5^{\circ}$ rise in temperature). The rivanol-ethanol purified material was pyrogenfree (rise in temperature less than $0.5^{\circ}$ ). The latter method was therefore used subsequently for purification.

The antitoxin titres of the horse globulins purified by the rivanol-ethanol method were considerably higher, namely 30,000 to 40,000 AT units/ml. compared with 20,000 to 24,000 AT units $/ \mathrm{ml}$. using the rivanol-ammonium sulphate method (Table 2). All of these partially purified and non-adsorbed antitoxin sera contained, in addition to antitoxins, agglutinins and vibriocidal antibodies (respective titres $I: I 280$ to $\mathrm{I}: 5420$ and $\mathrm{I}: \mathrm{IO}^{5}$ to $\left.\mathrm{I}: \mathrm{I} \times \mathrm{IO}^{5}\right)$. In order to obtain a pure antitoxic product, absorption was performed with living suspensions of Vibrio cholerae strain $569 \mathrm{~B}$. This reduced the agglutinin and vibriocidal antibody titres to $I: 80$ and $I:$ I000 respectively without loss of the antitoxic titre.

\section{Tests in human volunteers}

Innocuity and immunogenicity. Purified toxin (fraction eluted from Sephadex G-200) was injected subcutaneously into three humans ( 25 loop units/person) and the results are shown in Table 3. High levels of the toxin-neutralizing antibodies were found in one person and lower levels in the other two. A simultaneous production of the agglutinins and vibriocidal antibodies also occurred, which indicated that additional bacterial fractions were present in this preparation. Apart from a slight mild local reaction at the site of inoculation, no untoward reactions were noted in the three volunteers. The investigation was then extended to 33 volunteers (Table 4). Reactions to the first injection of the toxoid were observed in only Io persons (group I) inoculated subcutaneously in the upper arm with the purified toxoid without adjuvant. Of these, six had increased temperatures up to $38^{\circ}$, three suffered from chills, headache and lassitude, and six had local reactions such as erythema, swelling and tenderness of the skin at the site of the injection which subsided after $48 \mathrm{~h}$. No local reaction occurred in volunteers injected intramuscularly with either adsorbed or inadsorbed toxoid.

The antibody response to two injections of the crude and partially purified toxoid is shown in Table 4. As can be seen, the increase in titre of agglutinins and vibriocidal antibodies was greater in the two groups immunized with the crude toxoid than in 


\section{Table 3. Antibody response of three volunteers to purified toxin from Vibrio cholerae 569 B}

A single dose of 25 loop units of purified toxin of Vibrio cholerae 569 в (preparation I I $3 / 67$, the fraction eluted from Sephadex G-200) was given subcutaneously without adjuvant. AGGL = titre of agglutinating antibodies for INABA strain 569 B and for OGAWA strain C 38383 . $\mathrm{VA}=$ titre of vibriocidal antibodies, and $\mathrm{AT}=$ titre of antitoxic antibodies (as units/ml.). n.t. = Not tested.

Volunteers

Serum titres

$\overbrace{\text { INABA }}^{I} \overbrace{\text { OGAWA }}^{\text {INABA }}$

Before immunization

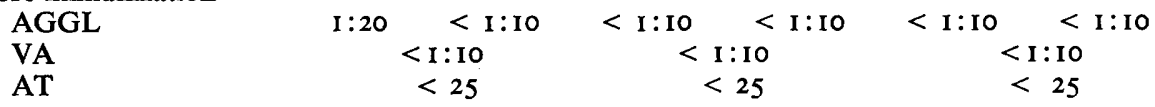

Two weeks after immunization AGGL VA

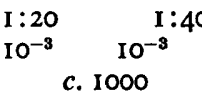

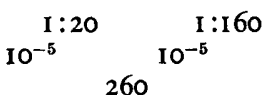
$10^{-5}: 40 \quad 100^{10^{-5}: 80}$

Five weeks after immunization
AGGL
VA
$\begin{array}{lr}\mathrm{I}: 80 & \text { n.t. } \\ 10^{-4} & 10^{-3} \\ \text { c. } 280^{-3}\end{array}$
$\mathrm{IO}^{\mathrm{I}: 320} \operatorname{loo}^{\mathrm{IO}^{-5}}$
$\underset{10^{-4}}{\text { I: }}$
c. 300

\section{Table 4. Antibody response of volunteers to cholera toxoid}

The volunteers (33) were divided into four groups: only group I received the toxoid subcutaneously; the other groups received toxoid intramuscularly. Purified toxoid (15 loop units in $0.5 \mathrm{ml}$. physiological saline, preparation $\mathrm{I}$ 1 $3 / 67$ from Vibrio cholerae strain $569 \mathrm{~B}$ ) was given to groups I and 2, and crude toxoid ( 30 loop units in $0.5 \mathrm{ml}$. physiological saline, preparation $05 \mathrm{~F} / 68$ ) to groups 3 and 4 . The adjuvant was aluminium phosphate $(2 \mathrm{mg}$./dose). All volunteers received a booster dose of crude toxoid $(05 \mathrm{~F} / 68)$ with adjuvant 3 weeks after the first injection. AGGA = agglutinating antibodies; $\mathrm{VA}=$ vibriocidal antibodies determined by the microtechnique of Benenson et al. (1968); AT = antitoxic antibodies (as units/ml.).

Purified toxoid

$\overbrace{\begin{array}{c}\text { Group 1 } \\ \text { (toxoid alone) }\end{array}}^{\begin{array}{c}\text { Group 2 } \\ \text { (toxoid with } \\ \text { adjuvant) }\end{array}}$

Before immunization

$\begin{array}{lll}\text { AGGL } & <1: 10 & <1: 10 \\ \text { VA } & <I: 10 & <1: 10 \\ \text { AT } & <25 & <25\end{array}$

Three weeks after

immunization

(before booster)

AGGL
VA
AT

Six weeks after immunization

$\begin{array}{ll}\text { AGGL } & 1: 480 \\ \text { VA } & 1: 320\end{array}$

AT

$\begin{array}{ll}1: 120 & 1: 80 \\ 1: 160 & c .50^{1: 160}\end{array}$

c. 200
I : 80
$1: 160$

c. 100

\begin{tabular}{|c|c|}
\hline \multicolumn{2}{|c|}{ Crude toxoid } \\
\hline $\begin{array}{c}\text { Group 3 } \\
\text { (toxoid alone) }\end{array}$ & $\begin{array}{l}\text { Group } 4 \\
\text { (toxoid with } \\
\text { adjuvant) } \dagger\end{array}$ \\
\hline < I:IO & < I:IO \\
\hline$<1: 10$ & $<1: 10$ \\
\hline$<25$ & $<25$ \\
\hline
\end{tabular}

$$
\begin{aligned}
& 1: 640 \\
& 1: 1280 \\
< & 25
\end{aligned}
$$$$
\text { :. } 50
$$

I $: 240$

I: 640

c. 50

c. 150 
those immunized with the partially purified toxoid. The antitoxin response was less satisfactory, the maximum titre reached being about $200 \mathrm{units} / \mathrm{ml}$. The addition of the aluminium phosphate seems to have increased only the titres of the agglutinins and vibriocidal antibodies.

\section{DISCUSSION}

The present procedure for immunization against cholera is unsatisfactory as the bacterial vaccine currently in use gives an immunity of short duration ( 3 to 6 months) and in only 50 to $60 \%$ of those vaccinated. As it is now known that cholera toxin plays a role in the pathogenesis of cholera, it seemed reasonable to investigate the value of antigens prepared from cholera toxin as immunizing agents. In our study we have prepared cholera toxin in various media according to the methods of Finkelstein et al. (1964) and Burrows (I968). In the first instance we have ascertained that the toxin is produced to a different degree by all the strains which we have studied. We have chosen the strain $569 \mathrm{~B}$ as the one producing maximal quantities of the toxin and Bactopeptone water as the medium for the toxin production. Our attempts to purify the toxin from the crude metabolic fluid have resulted in a relatively pure toxin; but in human volunteers and in immunized animals low titres of agglutinins and vibriocidal antibodies were found, indicating that small amounts of antigens other than toxin were present in the inoculum. In this context it is interesting to note that the addition of an aluminium phosphate adjuvant increased the titres of agglutinins and vibriocidal antibodies but not of the antitoxin. The toxin injected parenterally to human volunteers was well tolerated and can therefore be used as such for immunization. It seemed to us, however, desirable to have it stabilized by formaldehyde and to use the toxoid for our immunological investigations. It is desirable to have further studies in experimental animals and in man to assess the immunizing capacity of cholera whole-cell vaccines compared with the action of toxoids alone and toxoids combined with other fractions present in the culture supernatants.

\section{REFERENCES}

Azurin, J. C., Cruz, A., Pesigan, T. P., Alvero, M., Camena, T., Suplido, R., Ledesma, L. \& Gomez, C. Z. (1967). A controlled field trial of the effectiveness of cholera and cholera EL TOR vaccines in the Philippines. Bulletin World Health Organization 37, 703-727.

Benenson, A. S., Anisa SaAd \& Mosley, W. H. (I968a). Serological studies in cholera. 2. The vibriocidal antibody response of cholera patients determined by a microtechnique. Bulletin World Health Organization $\mathbf{3}^{8}, \mathbf{2 7 7 - 2 8 5}$.

Benenson, A. S., Mosley, W. H., Fahimuddin, M. \& Oseasohn, R. O. (I968b). Cholera vaccine field trials in East Pakistan. 2. Effectiveness in the field. Bulletin World Health Organization $\mathbf{3}^{8}$, 359-372.

Burrows, W. (1968). Cholera toxins. Annual Review of Microbiology 22, 245-268.

CRAIG, J. P. (1965). A permeability factor (toxin) found in cholera stools and culture filtrates and its neutralization by convalescent cholera sera. Nature, London 207, 614-616.

Craig, J. P. (1966). Preparation of the vascular permeability factor of Vibrio cholerae. Journal of Bacteriology 92, 793-795.

De, S. M., Ghose, M. L. \& Sen, A. (1960). Activities of bacteria-free preparations from Vibrio cholerae. Journal of Pathology and Bacteriology 79, 373-380.

DutTa, N. K. \& HabBU, M. K. (1955). Experimental cholera in infant rabbits: a method for chemotherapeutic investigation. British Journal of Pharmacology ro, I53-159. 
FINKELSTEIN, R. A. (I962). Vibriocidal antibody inhibition (VAI) analysis: a technique for the identification of the predominant vibriocidal antibodies in serum and for the detection and identification of Vibrio cholerae antigens. Journal of Immunobiology 89, 264-27I.

Finkelstein, R. A., Norris, H. T. \& DutTA, N. K. (1964). Pathogenesis of experimental cholera in infant rabbits. I. Observations on the intra-intestinal infection and experimental cholera produced with cell-free products. Journal of Infectious Diseases Ir4, 203-2 I6.

Finkelstein, R. A., Atthasampunna, P., Chulasamaya, M. \& Charunmethee, P. (1966). Pathogenesis of experimental cholera: biologic activities of purified procholeragen A. Journal of Immunology 96, 440-449.

Goodner, K., Smith, H. L. Jun. \& Stempen, H. (1960). Serologic diagnosis of cholera. Journal of the Albert Einstein Medical Center 8, I45-I 47.

KasAI, J. \& BURrows, W. (1966). The titration of cholera toxin and antitoxin in the rabbit ileal loop. Journal of Infectious Diseases 116, 506-614.

Mosley, W. H., McCormack, W. M., Fahimuddin, M., Aziz, K. M. A., Mizanur Rahman, A. S. M., Alauddin Chowdury, A. K. M., Martin, A. R., Feeley, J. C. \& Phillips, R. A. (1969). Report of the 1966-67 cholera vaccine field trial in rural East Pakistan. 1. Study, design and results of the first year of observations. Bulletin World Health Organization 40, 177-185.

Oseasohn, R. O., Benenson, A. S. \& Fahimuddin, M. (1965). Field trials of cholera vaccine in rural East Pakistan. First year of observation. Lancet i, 450-453.

Sack, R. B., Barua, D., SAXena, R. \& CARPenter, C. J. (1966). Vibrocidal and agglutinating antibody patterns in cholera patients. Journal of Infectious Diseases II6, 630-640.

Sever, J. L. (1962). Application of a microtechnique to viral serological investigations. Journal of Immunology 88, 320-329.

Ungar, J., Chariatte, N., Stanić, M. \& Varallyay, S. (1969). Studies on cholera. (Xth International Congress for Microbiological Standardization, Prague, 1967.) Progress in Immunobiological Standardization 3, 357-362.

WatanABE, Y. \& VerWey, W. F. (1965). Protective antigens from EL TOR vibrios. I. The preparation and properties of a purified protective antigen from an EL TOR vibrio (OGAWA subtype). Bulletin of the World Health Organization 32, 809-821. 